\title{
Effect of Micronutrients on Growth, Seed Yield and Seed Quality of Wheat (Triticum aestivum L.)
}

\author{
Ambreesh Kumar Shukla ${ }^{1}$, Krishna Kumar Mishra ${ }^{2 *}$, \\ Nitish Sharma ${ }^{1}$ and Mayankar Singh ${ }^{1}$
}

\author{
${ }^{1}$ Department of Plant Physiology, NDUA\&T, Kumarganj, Faizabad, U.P., India \\ ${ }^{2}$ Department of Horticulture, NDUA\&T, Kumarganj, Faizabad, U.P., India
}

*Corresponding author

\begin{abstract}
A B S T R A C T
\section{Keywords}

Boron effect, seed yield and seed quality, wheat and zinc effect

Article Info

Accepted:

20 May 2018

Available Online:

10 June 2018

An experiment was carried out at Department of Plant Physiology, N. D. University of Agric. and Tech., Faizabad 2012-13. Experiment was conducted on wheat variety of PBW 343 to evaluate the effect of zinc and boron on seed yield and other quality parameters of wheat. Four doses of zinc viz, 0.0, 2.5, 5.0 and $7.5 \mathrm{~kg} \mathrm{ha}^{-1}$ and four doses of boron namely $0.0,0.5,1.0$ and $1.5 \mathrm{~kg} \mathrm{ha}^{-1}$ were applied. The results showed that the effect of $\mathrm{Zn}$ was significant to all the parameters except leaf area index at $60 \& 90$ DAS, chlorophyll intensity, canopy temperature depression, chlorophyll fluorescence, days to $50 \%$ heading, plant height, and days to maturity, spike length and seed length. However, application of boron exhibited significant effect with respect to leaf area index at 30 DAS, plant height, number of tillers per $\mathrm{m}^{2}$, raw and graded seed yield, seed length, 1000 seed weight, standard germination per cent, seedling length and seedling vigour index. The $7.5 \mathrm{~kg} \mathrm{Zn}$ and $1.5 \mathrm{~kg} \mathrm{~B} \mathrm{ha}^{-1}$ have been found to be most appropriate for increasing seed yield and seed quality of wheat crop.
\end{abstract}

\section{Introduction}

Wheat (Triticum aestivum L.) is the leading food crop in world farming. It is main food crop of temperate zone. It is also extended to warm regions of temperate and sub tropics to tropical low lands. India is probably one of the few countries in the world where three wheat types are grown. The major area i.e. 86 per cent, is under bread wheat (Triticum aestivum L.), about 12 per cent under durum wheat (Triticum turgidum L.) and the remaining under dicoccum wheat (Triticum monococcum L.). India is the second largest producer of wheat in the world next only to China and the crop has provided the fastest pace of growth to Indian agriculture.

In India, wheat is next only to rice among the cereals, cultivated over an area of $29.86 \mathrm{~m}$ ha with a total production and productivity of $92.45 \mathrm{~m} \mathrm{t}$ and 3.1 tonnes $\mathrm{ha}^{-1}$, respectively during 2012- 13. Wheat contains 12.6-14 g protein, 1.5-1.9 g fat, 68-71 g carbohydrate, $12.2 \mathrm{~g}$ dietary fibre, $360 \mathrm{kcal}$ energy, $39 \mathrm{mg}$ calcium, $239 \mathrm{mg}$ magnesium, $842 \mathrm{mg}$ phosphorus, $892 \mathrm{mg}$ potassium, $12.29 \mathrm{mg}$ zinc and $6.26 \mathrm{mg}$ of iron, $17-20$ per cent of the 
daily requirement in human body. (Watt and Breyer-Brandwijk, 1962. USDA Nutrient Database, 2006). The importance of micronutrients application in increasing crop production has been recognized in India and it is becoming evident that without the use of the micronutrient, it is not possible to get the maximum benefits of NPK fertilizers and high yielding varieties of wheat (Shukla and Warsi 2000). Excess or deficiency of certain elements from the crop can affect its yield, quality and subsequent post-harvest life.

Zinc is an essential micronutrient for plant growth and is absorbed by the plant roots in the form of $\mathrm{Zn}^{2+}$. It is involved in diverse metabolic activities, influences the activities of hydrogenase and carbonic anhydrase, synthesis of cytochrome and the stabilization of ribosomal fractions and auxin metabolism (Tisdale, et al., 1984). Due to the deficiency of zinc, plant exhibits poor growth, interveinal chlorosis and necrosis of lower leaves. Reddish or brownish spot often occurs on the older leaves and ultimately seed production is strikingly reduced due to its deficiency (Throne, D.W. 1957). Zinc deficiency also decreases nutritional quality of wheat grain and contributes to health problems in human beings, mainly in developing countries where cereals are major staple food (Kalayci, et al., 1999).

Owing due to high demand of zinc by rice plant, a little amount of zinc is left in the soil which is supposed to be least available to wheat crop. Under such circumstances growth yielding ability and seed quality of wheat is badly affected. Hence, it is obvious to find out suitable level of zinc requirement for optimal growth, better yield and seed quality of the crop.

Seed and grain production are reduced with low boron supply. A primary function of boron is related to cell wall formation, so boron-deficient plants may be stunted. Sugar transport in plants, flower retention and pollen formation and germination also are affected by boron. Boron-deficiency symptoms first appear at the growing points. This results in a stunted appearance (rosetting), barren ears due to poor pollination, hollow stems and fruit (hollow heart) and brittle, discoloured leaves and loss of fruiting bodies. Borate ions are mobile in soil and can be leached from the root zone. Boron deficiencies are more pronounced during drought periods when root activity is restricted.

\section{Materials and Methods}

Experiment was conducted at Department of Plant Physiology, N. D. University of Agric. and Tech., Faizabad Rabi 2012-13 to assess the seed yield and quality parameters of wheat variety PBW 343. The experiment was laid out in Factorial RBD. The crop was sown on $2^{\text {th }}$ December 2013 using a seed rate of 100 $\mathrm{Kg} \mathrm{ha}{ }^{-1}$ at row spacing of $23.0 \mathrm{~cm}$. A recommended dose of NPK 120:60:40 $\mathrm{Kg} \mathrm{ha}^{-1}$ were applied. There were 16 treatment combinations with four doses of Zinc viz. 0.0, 2.5, 5.0 and $7.5 \mathrm{~kg} \mathrm{ha}^{-1}$ and four doses of Boron namely $0.0,0.5,1.0$ and $1.5 \mathrm{~kg} \mathrm{ha}^{-1}$ were applied in the form of Zinc Sulphate (21\% Zinc) and Borax (10.5\% Boron), respectively. One hoeing and weeding was done 30 days after sowing (DAS). On 10 randomly selected plants yield contributing and morpho-physiological characters were recorded from each plot i.e. days to $50 \%$ heading, plant height, leaf area index, specific leaf weight, chlorophyll intensity, canopy temperature depression, chlorophyll fluorescence, number of tillers sqm ${ }^{-1}$, number of seeds spike ${ }^{-1}$, spike length, days to maturity, raw seed yield $\mathrm{q} \mathrm{ha}{ }^{-1}$, graded seed yield $\mathrm{q} \mathrm{ha}{ }^{-1}$ and quality parameters in lab i.e. seed length, seed breadth, 1000 seed weight, standard germination, seedling length and seedling vigour index. 


\section{Results and Discussion}

Significant influence of $\mathrm{Zn} \& \mathrm{~B}$ application was found for leaf area index at 30 DAS, number of tillers, 1000 seed weight, raw and graded seed yield, standard germination, seedling length and seedling vigour index but specific leaf weight, number of seeds spike ${ }^{-1}$ and seed breadth were effected significantly by application of zinc whereas plant height and seed length by application of boron (Table- 1, $2 \& 3$ ).

The interaction of zinc $\times$ boron showed nonsignificant effect with respect to all parameters.

Application of $7.5 \mathrm{~kg} \mathrm{Zn} \mathrm{ha}{ }^{-1}$ exhibited significantly maximum leaf area index at 30 DAS (1.68) and specific leaf weight $(6.65$ $\mathrm{mg} / \mathrm{cm}^{2}$ ). The later findings confirm the results reported by (Singh, et al., 2009) in wheat. The number of tillers increased significantly with increase in $\mathrm{Zn}$ level over control.

Similar finding have been reported by (Sharma, et al., 2008). Highest raw seed yield $42.68 \mathrm{q} \mathrm{ha}^{-1}$ as well as graded seed yield $\left(40.80 \mathrm{q} \mathrm{ha}^{-1}\right)$ was observed in $7.5 \mathrm{~kg} \mathrm{Zn} \mathrm{ha}{ }^{-1}$. This findings are in conformity to the results obtained by Singh, et al., (2009), Rather and Sharma, (2009) and Tyagi, et al., (2011) in wheat.

The maximum seed breadth $(3.52 \mathrm{~mm})$ was observed in $7.5 \mathrm{~kg} \mathrm{Zn} \mathrm{ha}^{-1}$. The profound effect of $\mathrm{Zn}$ in increasing 1000 seed weight of wheat have been found and significantly highest $(43.20$ g) 1000 seed weight was produced by the treatment $7.5 \mathrm{~kg} \mathrm{Zn} \mathrm{ha}{ }^{-1}$, while lowest $(40.51 \mathrm{~g})$ was found in control. Similar finding have been reported by Kharub and Gupta (2003) \& Zeidan, et al., (2010) in wheat. The standard germination $(83.25 \%)$, seedling length $(25.57 \mathrm{~cm})$ and seedling vigour index (2520.90) was found significantly superior as compared to others at dose of $7.5 \mathrm{~kg}$ zinc ha ${ }^{-1}$. However, number of seeds spike ${ }^{-1}$ was found superior at $5.0 \mathrm{~kg} \mathrm{Zn}$ $\mathrm{ha}^{-1}$ The application of zinc sulphate did not influence the leaf area index at 60 and 90 DAS, chlorophyll intensity, canopy temperature depression, chlorophyll fluorescence, days to $50 \%$ heading, plant height, days to maturity, spike length and seed length.

The dose of $1.5 \mathrm{~kg} \mathrm{~B} \mathrm{ha}{ }^{-1}$ showed maximum leaf area index at 30 DAS (1.63) which was significantly higher from control (1.52). The higher doses of boron $\left(1.0 \mathrm{~kg} \mathrm{ha}^{-1} \& 1.5 \mathrm{~kg} \mathrm{ha}^{-}\right.$ $\left.{ }^{1}\right)$ had significantly accelerated the plant height $(87.30 \& 87.73 \mathrm{~cm})$ and number of tillers ( $346.08 \& 349.08$ per $\mathrm{m}^{2}$ ), whereas, the significantly highest raw seed yield $(42.58 \mathrm{q}$ $\left.\mathrm{ha}^{-1}\right)$, graded seed yield (41.09 $\left.\mathrm{q} \mathrm{ha}^{-1}\right)$ and 1000 seed weight $(41.96 \mathrm{~g})$ were found by application of $1.5 \mathrm{~kg} \mathrm{~B} \mathrm{ha}^{-1}$. Similar findings have been reported by (Moeinian, et al., (2011), \& Esringu, et al., (2011), in wheat. In the present investigation, a profound effect of boron on wheat has been found. As the boron level increased the yield was also enhanced that indicates positive association between boron levels and graded seed yield. Significantly maximum quality in terms of 1000 seed weight (42.96 g), Seed length (7.32 $\mathrm{mm})$, standard germination (82.08\%), seedling length $(25.20 \mathrm{~cm})$ and seedling vigour index (2469.93) were also found when applied 1.5 $\mathrm{kg} \mathrm{B} \mathrm{ha}{ }^{-1}$.

These results are in conformity with the findings of (Muhammad, et al., (2009) in wheat. However, boron application did not influence the leaf area index at $60 \& 90$ DAS, specific leaf weight, chlorophyll intensity, canopy temperature depression, chlorophyll fluorescence, days to $50 \%$ heading, days to maturity, spike length, number of seeds per spike and seed breadth. 
Table.1 Mean effect of Zinc and Boron on morpho-physiological parameters of wheat Variety PBW 343

\begin{tabular}{|c|c|c|c|c|c|c|c|}
\hline Treatment & $\begin{array}{l}\text { Leaf Area } \\
\text { Index } 30 \\
\text { DAS }\end{array}$ & $\begin{array}{c}\text { Leaf Area } \\
\text { Index } 60 \\
\text { DAS }\end{array}$ & $\begin{array}{c}\text { Leaf Area } \\
\text { Index } 90 \\
\text { DAS }\end{array}$ & $\begin{array}{l}\text { Chlorophyll } \\
\text { Intensity }\end{array}$ & $\begin{array}{c}\text { Canopy } \\
\text { Temperature } \\
\text { Depression }\left({ }^{0} \mathrm{C}\right)\end{array}$ & $\begin{array}{c}\text { Specific Leaf } \\
\text { Weight (SLW) } \\
\left(\mathrm{mg} / \mathrm{cm}^{2}\right)\end{array}$ & $\begin{array}{l}\text { Chlorophyll } \\
\text { Fluorescence } \\
\text { (Fv/Fm) }\end{array}$ \\
\hline $0.0 \mathrm{~kg} \mathrm{ha}^{-1}\left(\mathrm{Zn}_{0}\right)$ & 1.50 & 2.45 & 3.48 & 45.63 & 4.35 & 6.22 & 0.752 \\
\hline $2.5 \mathrm{~kg} \mathrm{ha}^{-1}\left(\mathrm{Zn}_{1}\right)$ & 1.54 & 2.55 & 3.48 & 45.89 & 4.77 & 6.29 & 0.753 \\
\hline $5.0 \mathrm{~kg} \mathrm{ha}^{-1}\left(\mathrm{Zn}_{2}\right)$ & 1.53 & 2.52 & 3.55 & 45.43 & 4.65 & 6.57 & 0.756 \\
\hline $7.5 \mathrm{~kg} \mathrm{ha}^{-1}\left(\mathrm{Zn}_{3}\right)$ & 1.68 & 2.62 & 3.61 & 45.10 & 4.80 & 6.65 & 0.759 \\
\hline SE $(d)$ & 0.03 & 0.07 & 0.07 & 0.41 & 0.19 & 0.12 & 0.005 \\
\hline$C D(p=0.05)$ & 0.07 & NS & NS & NS & $\mathbf{N S}$ & 0.25 & NS \\
\hline $0.0 \mathrm{~kg} \mathrm{ha}^{-1}\left(\mathrm{~B}_{0}\right)$ & 1.52 & 2.48 & 3.47 & 46.01 & 4.52 & 6.39 & 0.749 \\
\hline $0.5 \mathrm{~kg} \mathrm{ha}^{-1}\left(\mathrm{~B}_{1}\right)$ & 1.53 & 2.52 & 3.52 & 45.44 & 4.70 & 6.42 & 0.755 \\
\hline $1.0 \mathrm{~kg} \mathrm{ha}^{-1}\left(\mathrm{~B}_{2}\right)$ & 1.56 & 2.57 & 3.55 & 45.17 & 4.67 & 6.37 & 0.758 \\
\hline $1.5 \mathrm{~kg} \mathrm{ha}^{-1}\left(\mathrm{~B}_{3}\right)$ & 1.63 & 2.57 & 3.58 & 45.43 & 4.69 & 6.51 & 0.758 \\
\hline SE(d) & 0.03 & 0.07 & 0.07 & 0.41 & 0.19 & 0.12 & 0.005 \\
\hline $\mathrm{CD}(\mathrm{p}=0.05)$ & 0.07 & NS & NS & NS & NS & NS & $\mathbf{N S}$ \\
\hline
\end{tabular}

Table.2 Mean effect of Zinc and Boron on seed yield and quality parameters of wheat Variety PBW 343

\begin{tabular}{|c|}
\hline Treatment \\
\hline $0.0 \mathrm{~kg} \mathrm{ha}^{-1}\left(\mathbf{Z n}_{0}\right)$ \\
\hline $2.5 \mathrm{~kg} \mathrm{ha}^{-1}\left(\mathbf{Z n}_{1}\right)$ \\
\hline $5.0 \mathrm{~kg} \mathrm{ha}^{-1}\left(\mathbf{Z n}_{2}\right)$ \\
\hline $7.5 \mathrm{~kg} \mathrm{ha}^{-1}\left(\mathbf{Z n}_{3}\right)$ \\
\hline $\mathbf{S E}(\mathbf{d})$ \\
\hline $\mathrm{CD}(\mathbf{p}=\mathbf{0 . 0 5})$ \\
\hline $0.0 \mathrm{~kg} \mathrm{ha}^{-1}\left(\mathbf{B}_{\mathbf{0}}\right)$ \\
\hline $0.5 \mathrm{~kg} \mathrm{ha}^{-1}\left(\mathbf{B}_{1}\right)$ \\
\hline $1.0 \mathrm{~kg} \mathrm{ha}^{-1}\left(\mathbf{B}_{2}\right)$ \\
\hline $1.5 \mathrm{~kg} \mathrm{ha}^{-1}\left(\mathbf{B}_{3}\right)$ \\
\hline $\mathrm{SE}(\mathbf{d})$ \\
\hline $\mathrm{CD}(\mathbf{p = 0 . 0 5})$ \\
\hline
\end{tabular}

\begin{tabular}{|c|c|c|c|c|c|c|}
\hline $\begin{array}{c}\text { Days to } 50 \% \\
\text { Heading }\end{array}$ & $\begin{array}{c}\text { Plant Height } \\
(\mathrm{cm})\end{array}$ & $\begin{array}{l}\text { Days to } \\
\text { Maturity } \\
\text { (DAS) }\end{array}$ & $\begin{array}{l}\text { Number of } \\
\text { Tillers/ } \mathbf{m}^{2}\end{array}$ & Spike Length (cm) & $\begin{array}{c}\text { Number of } \\
\text { Seeds Spike }^{-1}\end{array}$ & $\begin{array}{l}\text { Seed Length } \\
(\mathrm{mm})\end{array}$ \\
\hline 84.33 & 86.33 & 126.92 & 332.92 & 8.62 & 48.18 & 7.17 \\
\hline 84.41 & 86.04 & 126.00 & 341.00 & 8.93 & 51.41 & 7.22 \\
\hline 84.91 & 87.19 & 126.00 & 347.75 & 8.87 & 52.95 & 7.25 \\
\hline 84.83 & 87.47 & 126.00 & 349.08 & 8.92 & 51.87 & 7.17 \\
\hline 0.48 & 0.68 & 0.28 & 4.65 & 0.23 & 0.53 & 0.00 \\
\hline NS & NS & NS & 9.49 & NS & 1.09 & NS \\
\hline 84.33 & 85.59 & 126.50 & 333.17 & 8.58 & 50.28 & 7.11 \\
\hline 84.75 & 86.53 & 126.33 & 339.83 & 8.81 & 51.55 & 7.17 \\
\hline 84.91 & 87.30 & 126.58 & 346.08 & 8.91 & 51.23 & 7.22 \\
\hline 84.50 & 87.73 & 126.33 & 349.67 & 9.03 & 51.35 & 7.32 \\
\hline 0.48 & 0.68 & 0.28 & 4.65 & 0.23 & 0.53 & 0.00 \\
\hline NS & 1.40 & NS & 9.49 & NS & NS & 0.01 \\
\hline
\end{tabular}


Table.3 Mean effect of Zinc and Boron on germination and seed quality parameters of wheat Variety PBW 343

\begin{tabular}{|c|c|c|c|c|c|c|c|}
\hline Treatment & $\begin{array}{c}\text { Seed } \\
\text { Breadth } \\
(\mathrm{mm})\end{array}$ & $\begin{array}{l}1000 \text { Seed } \\
\text { Weight }(\mathrm{g})\end{array}$ & $\begin{array}{c}\text { Raw Seed } \\
\text { Yield (q ha } \\
\text { 1) }\end{array}$ & $\begin{array}{l}\text { Graded Seed } \\
\text { Yield }\left(\mathbf{q} \mathbf{h a}^{-1}\right)\end{array}$ & $\begin{array}{c}\text { Standard } \\
\text { Germination }(\%)\end{array}$ & $\begin{array}{c}\text { Seedling } \\
\text { Length }(\mathrm{cm})\end{array}$ & $\begin{array}{l}\text { Seedling Vigour } \\
\text { Index (SVI) }\end{array}$ \\
\hline $0.0 \mathrm{~kg} \mathrm{ha}^{-1}\left(\mathrm{Zn}_{0}\right)$ & 3.37 & 40.51 & 39.33 & 38.13 & 79.10 & 24.10 & 2325.98 \\
\hline $2.5 \mathrm{~kg} \mathrm{ha}^{-1}\left(\mathrm{Zn}_{1}\right)$ & 3.40 & 40.66 & 39.84 & 38.45 & 79.49 & 24.46 & 2385.67 \\
\hline $5.0 \mathrm{~kg} \mathrm{ha}^{-1}\left(\mathrm{Zn}_{2}\right)$ & 3.46 & 40.71 & 41.17 & 39.92 & 81.22 & 25.41 & 2455.29 \\
\hline $7.5 \mathrm{~kg} \mathrm{ha}^{-1}\left(\mathrm{Zn}_{3}\right)$ & 3.52 & 43.20 & 42.68 & 40.80 & 83.25 & 25.57 & 2520.90 \\
\hline $\operatorname{SE}(d)$ & 0.00 & 0.53 & 0.60 & 0.43 & 0.80 & 0.22 & 25.55 \\
\hline CD $(p=0.05)$ & 0.07 & 1.08 & 1.23 & 0.90 & 1.63 & 0.45 & 52.17 \\
\hline $0.0 \mathrm{~kg} \mathrm{ha}^{-1}\left(\mathrm{~B}_{0}\right)$ & 3.41 & 39.64 & 39.34 & 38.12 & 79.67 & 24.49 & 2367.31 \\
\hline $0.5 \mathrm{~kg} \mathrm{ha}^{-1}\left(\mathrm{~B}_{1}\right)$ & 3.43 & 40.55 & 40.08 & 38.57 & 80.62 & 24.86 & 2416.35 \\
\hline $1.0 \mathrm{~kg} \mathrm{ha}^{-1}\left(\mathrm{~B}_{2}\right)$ & 3.46 & 41.89 & 40.92 & 39.62 & 80.88 & 25.00 & 2434.25 \\
\hline $1.5 \mathrm{~kg} \mathrm{ha}^{-1}\left(\mathrm{~B}_{3}\right)$ & 3.46 & 42.96 & 42.58 & 41.09 & 82.08 & 25.20 & 2469.93 \\
\hline SE(d) & 0.00 & 0.53 & 0.60 & 0.43 & 0.80 & 0.22 & 25.55 \\
\hline $\mathrm{CD}(\mathrm{p}=0.05)$ & NS & 1.08 & 1.23 & 0.90 & 1.63 & 0.45 & 52.17 \\
\hline
\end{tabular}

Interaction $\mathrm{Zn} \times \mathrm{B}(\mathrm{Zinc} \times$ Boron) were found non-significant (NS). 
The dose $7.5 \mathrm{~kg} \mathrm{Zn}$ and $1.5 \mathrm{~kg} \mathrm{~B} \mathrm{ha}{ }^{-1}$ have been found to be the most appropriate in enhancing the seed yield over control i.e. 7.26 and 7.79 per cent, respectively, with maximum seed quality in terms of germination and vigour.

\section{Acknowledgement}

This study has been supported by Department of Plant Physiology, N. D. University of Agric. and Tech., Faizabad to providing all necessary facilities.

\section{References}

Esringu, A.; Turan, M.; Gunes, A.; Ataoglu, N. and Uzun, O. (2011). Optimum economic boron fertilizer doses of wheat grown on calcareous soil. J. of Plant Nutrition. 34 (11): 1625-1641.

Kalayci, M.; Torun, B.; Eker, S.; Aydin, M.; Ozturk, L. and Cakmak, I. (1999). Grain yield, zinc efficiency and zinc concentration of wheat cultivars grown in a zinc-deficient calcareous soil in field and greenhouse. Field Crops Res., 63: 87-98.

Kharub, A. S. and Gupta, S. P. (2003). Quality traits in durum and aestivum wheat genotypes as influenced by $\mathrm{Zn}$ application. Indian J. of Agric. Res. 37 (1): 48-51.

Moeinian, M. R.; Zargari, K. and Hasanpour, J. (2011). Effect of boron foliar spraying application on quality characteristics and growth parameters of wheat grain under drought stress. American-Eurasian J. of Agric. \& Environmental Sci. 10 (4): 593-599.

Muhammad, A. T.; Shah, T.; Naeem, T. H. and Allah, W. F. (2009). Yield response of wheat (Triticum aestivum L.) to boron application at different growth stages. Pakistan Journal of Life and Social Sciences. 7 (1): 39-42.
Rather, S. A. and Sharma, N. L. (2009). Effect of integrated nutrient management (INM) on yield and economics of wheat. Asian J. of Soil Sci. 4 (1): 15-17.

Sharma, R.; Agarwal, A. and Kumar, S. (2008). Effect of micronutrients on protein content and productivity of wheat (Triticum aestivum L.). Vegetos. 21 (1): 51-53.

Shukla, S. K. and Warsi, A. S. (2000). Effect of sulphur and micronutrients on growth, nutrients content and yield of wheat (Triticum aestivam L.). Indian J. Agric. Res., 34 (3): 203-205.

Singh, B. R.; Singh, R. V. and Rajput, O. P. (2009). Effect of nitrogen, phosphorus and zinc on growth, yield and nutrient uptake of wheat (Triticum aestivum L). Current Adv. in Agric. Sci. 1 (2): 133134.

Singh, N. B.; Vinay, Kumar.; Singh, G. S.; Singh, Y. P.; Singh, I. J.; Kumar, J.; Singh, K. N. and Srivastava, J. K. (2009). Variability in response to zinc application in wheat genotypes. Ind. J. of Plant physiol. 14 (4): 413-417.

Throne, D.W. (1957). Zinc deficiency and its control. Adv. Agron., 9: 31-65.

Tisdale, S. L.; Nelson, W. L. and Beaten, J. D. (1984). Zinc in Soil Fertility and Fertilizers, $\quad 4^{\text {th }}$ Ed., Macmillan Publishing Company, New York, USA pp: 382-391.

Tyagi, S.; Mahapatra, B. S.; Tyagi, K. and Ansari, M. A. (2011). Nutrient dynamics and yield as affected by micronutrient nutrition in wheat (Triticum aestivum L.). Flora and Fauna (Jhansi). 17 (1): 53-58.

Zeidan, M. S.; Mohamed, M. F. and Hamouda, H. A. (2010). Effect of Foliar Fertilization of $\mathrm{Fe}, \mathrm{Mn}$ and $\mathrm{Zn}$ on Wheat Yield and Quality in Low Sandy Soils Fertility. World J. Agric. Sci., 6 (6): 696-699. 


\section{How to cite this article:}

Ambreesh Kumar Shukla, Krishna Kumar Mishra, Nitish Sharma and Mayankar Singh. 2018. Effect of Micronutrients on Growth, Seed Yield and Seed Quality of Wheat (Triticum aestivum L.). Int.J.Curr.Microbiol.App.Sci. 7(06): 2865-2871. doi: https://doi.org/10.20546/ijcmas.2018.706.337 